\title{
Nowoczesne leczenie pacjenta z nadciśnieniem tętniczym i bardzo wysokim ryzykiem zdarzeń sercowo-naczyniowych
}

\author{
Modern treatment for a very high cardiovascular risk patient \\ with arterial hypertension
}

\author{
Filip Dybowski, Małgorzata Lelonek
}

Zakład Kardiologii Nieinwazyjnej Katedry Chorób Wewnętrznych i Kardiologii Uniwersytetu Medycznego w Łodzi

\section{Streszczenie}

W nowych wytycznych ESC/ESH dotyczących diagnostyki i leczenia nadciśnienia tętniczego (AH) z 2018 roku po raz kolejny podkreślono znaczenie oceny globalnego ryzyka sercowo-naczyniowego (CV) u pacjentów z AH. Ocena globalnego ryzyka CV determinuje wybór postępowania oraz strategii leczenia. W aktualnych wytycznych ESC/ESH AH 2018 leczenie skojarzone, najlepiej w jednej tabletce, jest rekomendowane od początku terapii nadciśnienia tętniczego. Leki złożone poprawiają adherence oraz są wygodniejsze dla pacjentów. W warunkach polskich 2 chorych na 3 z AH jest obciążonych hipercholesterolemią. W artykule przedstawiono przypadek kliniczny pacjenta z AH i obarczonego bardzo wysokim ryzykiem CV, u którego nowoczesne leczenie preparatami złożonymi (hipotensyjno-hipolipemizującymi) okazało się efektywne w krótkim czasie.

Słowa kluczowe: wytyczne, nadciśnienie tętnicze, preparaty złożone

Folia Cardiologica 2019; 14, 1: 112-119

\section{Wstęp}

W opublikowanych w 2018 roku wspólnych wytycznych Europejskiego Towarzystwa Kardiologicznego (ESC, European Society of Cardiology) oraz Europejskiego Towarzystwa Nadciśnienia Tętniczego (ESH, European Society of Hypertension) po raz kolejny podkreśla się znaczenie oceny globalnego ryzyka sercowo-naczyniowego (CV, cardiovascular) (tab. 1) u pacjentów z nadciśnieniem tętniczym, przy wyborze postępowania i strategii leczenia (tab. 2) [1]. Brak kontroli współistniejących czynników chorób układu sercowo-naczyniowego (CVD, cardiovascular diseases) może niwelować korzyści wynikające z obniżenia ciśnienia tętniczego. Na przykład według skali Pol-SCORE 2015 (tab. 3) [2] 55-letniego palącego mężczyznę ze skurczowym ciśnieniem tętniczym $140 \mathrm{~mm}$ Hg i stężeniem cholesterolu całkowitego $230 \mathrm{mg} / \mathrm{dl}$ cechuje takie samo ryzyko zgonu z przyczyn CV w ciągu 10 lat jak pacjenta ze skurczowym ciśnieniem tętniczym 160 mm Hg oraz stężeniem cholesterolu całkowitego 150 mg/dl (10\%). Warto zauważyć, że ten sam pacjent w przypadku zaprzestania palenia oraz skutecznego obniżenia wartości skurczowego ciśnienia tętniczego i cholesterolu całkowitego może 2-krotnie obniżyć 10-letnie ryzyko zgonu z przyczyn CV. Ograniczenie współistniejących czynników ryzyka jest zatem fundamentalnym elementem strategii postępowania u pacjenta z nadciśnieniem tętniczym.

\section{Opis przypadku}

Aktywnego zawodowo 68-letniego mężczyznę z przewlekłą chorobą wieńcową, obarczonego wieloma czynnikami ryzyka, tj. nadciśnieniem tętniczym, cukrzycą typu 2, hipercholesterolemią, przewlekłą obturacyjną chorobą płuc oraz nikotynizmem, cechuje również obciążający wywiad rodzinny w kierunku CVD - jego ojciec zmarł z powodu zawału serca w wieku 66 lat. Pacjent przebył zawał serca bez uniesienia odcinka ST leczony angioplastyką gałęzi okalającej z jednoczasową implantacją stentu uwalniającego lek (DES, drug-eluting stent) w 2016 roku. W koronarografii 
Tabela 1. Kategorie 10-letniego ryzyka sercowo-naczyniowego według SCORE na podstawie wytycznych leczenia nadciśnienia tętniczego European Society of Cardiology/European Society of Hypertension (ESC/ESH) z 2018 roku (źródło [1])

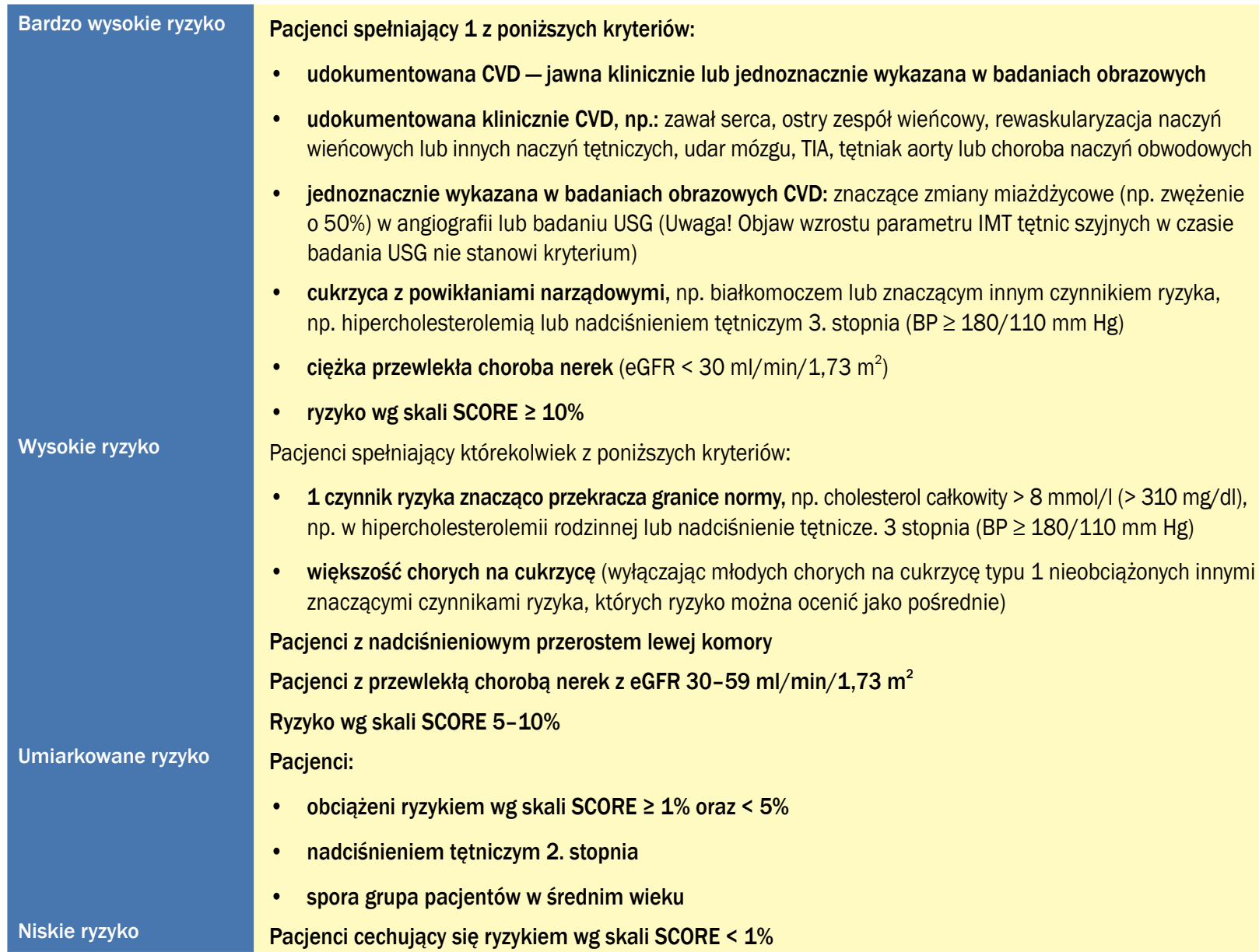

CVD (cardiovascular disease) - choroba układu sercowo-naczyniowego; TIA (transient ischaemic attack) - przejściowy napad niedokrwienny; USG - ultrasonograficzne; IMT (intima-media thickness) - grubość kompleksu błona wewnętrznej i środkowej; BP (blood pressure) - ciśnienie tętnicze; eGFR (estimated glomerular filtration rate) - szacowany współczynnik filtracji kłębuszkowej; SCORE - Systematic coronary Risk Evaluation

Tabela 2. Klasyfikacja stadium nadciśnienia tętniczego zależnie od wartości ciśnienia tętniczego, czynników ryzyka sercowo-naczyniowego, powikłań narządowych nadciśnienia tętniczego oraz chorób współistniejących (źródło [1])

\begin{tabular}{|c|c|c|c|c|c|}
\hline \multirow{2}{*}{$\begin{array}{l}\text { Stadium nadciś- } \\
\text { nienia tętniczego }\end{array}$} & \multirow{2}{*}{$\begin{array}{l}\text { Pozostałe czynniki } \\
\text { ryzyka, powikłania } \\
\text { narządowe lub choroby }\end{array}$} & \multicolumn{4}{|c|}{ Stopień [mm Hg] nadciśnienia tętniczego } \\
\hline & & $\begin{array}{l}\text { Wysokie prawidłowe } \\
\text { SBP 130-139 } \\
\text { DBP 85-89 }\end{array}$ & $\begin{array}{l}\text { Stopień } 1 . \\
\text { SBP 140-159 } \\
\text { DBP 90-99 }\end{array}$ & $\begin{array}{c}\text { Stopień } 2 . \\
\text { SBP 160-179 } \\
\text { DBP 100-109 }\end{array}$ & $\begin{array}{l}\text { Stopień } 3 \\
\text { SBP } \geq 180 \\
\text { DBP } \geq 110\end{array}$ \\
\hline \multirow[t]{3}{*}{$\begin{array}{l}\text { Stadium } 1 . \\
\text { (niepowikłane) }\end{array}$} & $\begin{array}{c}\text { Brak innych czynników } \\
\text { ryzyka }\end{array}$ & Niskie ryzyko & Niskie ryzyko & $\begin{array}{l}\text { Umiarkowane } \\
\text { ryzyko }\end{array}$ & Wysokie ryzyko \\
\hline & 1 lub 2 czynniki ryzyka & Niskie ryzyko & $\begin{array}{c}\text { Umiarkowane } \\
\text { ryzyko }\end{array}$ & $\begin{array}{l}\text { Umiarkowane- } \\
\text {-wysokie ryzyko }\end{array}$ & Wysokie ryzyko \\
\hline & $\geq 3$ czynniki ryzyka & $\begin{array}{l}\text { Niskie-umiarkowa- } \\
\text { ne ryzyko }\end{array}$ & $\begin{array}{l}\text { Umiarkowane- } \\
\text {-wysokie ryzyko }\end{array}$ & Wysokie ryzyko & Wysokie ryzyko \\
\hline $\begin{array}{l}\text { Stadium } 2 . \\
\text { (choroba } \\
\text { bezobjawowa) }\end{array}$ & $\begin{array}{c}\text { Powikłania narządowe, } \\
\text { CKD w stadium G3, } \\
\text { cukrzyca bez powikłań } \\
\text { narządowych }\end{array}$ & $\begin{array}{l}\text { Umiarkowane- } \\
\text {-wysokie ryzyko }\end{array}$ & Wysokie ryzyko & Wysokie ryzyko & $\begin{array}{c}\text { Wysokie-bardzo } \\
\text { wysokie ryzyko }\end{array}$ \\
\hline $\begin{array}{l}\text { Stadium } 3 . \\
\text { (choroba } \\
\text { pełnoobjawowa) }\end{array}$ & $\begin{array}{c}\text { Objawowa CVD, CKD } \\
\text { w stadium } \geq \mathrm{G} 4, \\
\text { cukrzyca z powikłaniami } \\
\text { narządowymi }\end{array}$ & $\begin{array}{c}\text { Bardzo wysokie } \\
\text { ryzyko }\end{array}$ & $\begin{array}{c}\text { Bardzo wysokie } \\
\text { ryzyko }\end{array}$ & $\begin{array}{c}\text { Bardzo wysokie } \\
\text { ryzyko }\end{array}$ & $\begin{array}{c}\text { Bardzo wysokie } \\
\text { ryzyko }\end{array}$ \\
\hline
\end{tabular}




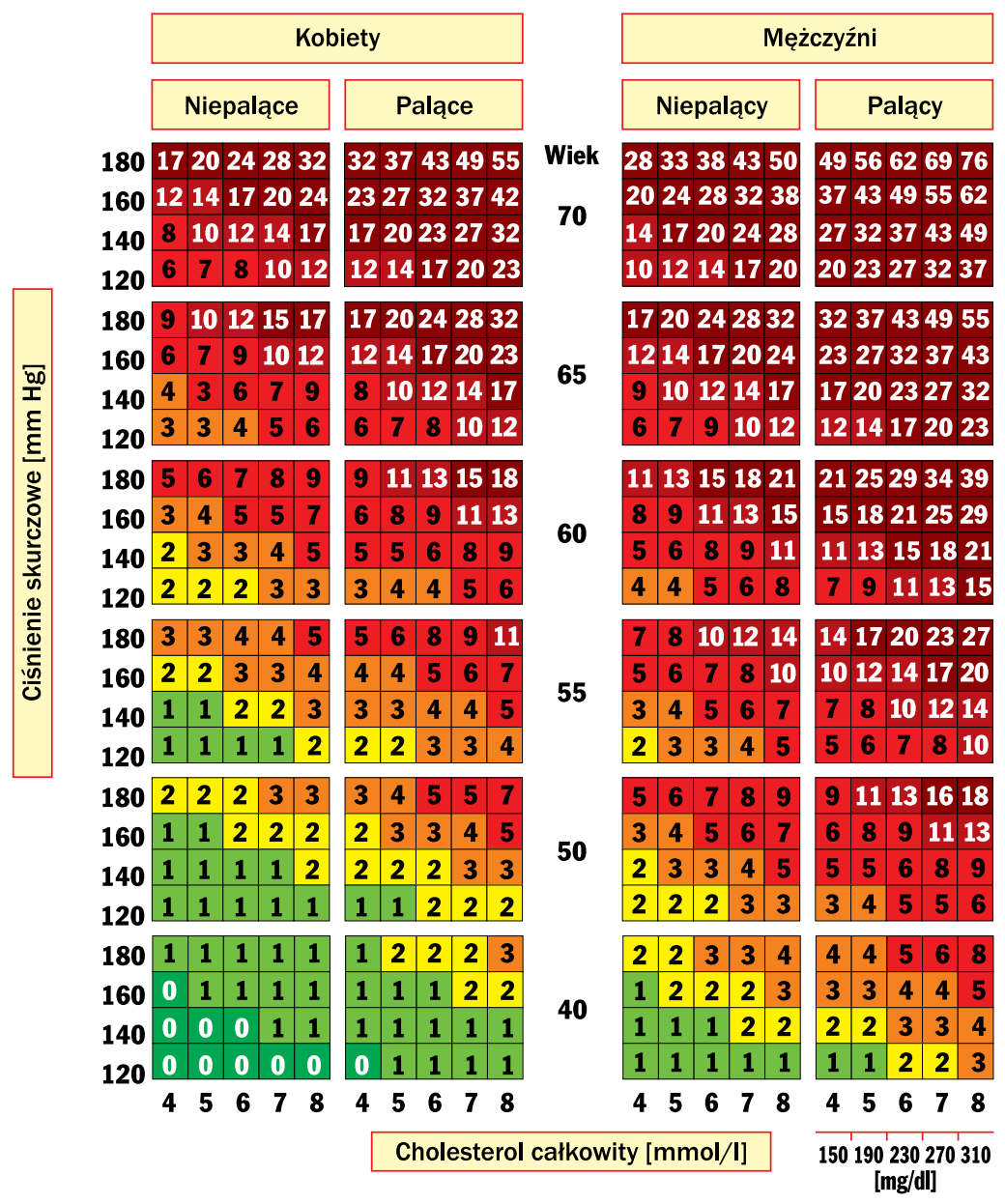

\begin{tabular}{|l|}
\hline $15 \%$ i więcej \\
\hline $10-14 \%$ \\
$5-9 \%$ \\
\hline $3-4 \%$ \\
\hline $2 \%$ \\
\hline $1 \%$ \\
$<1 \%$ \\
\hline
\end{tabular}

Tabela 3. Uaktualniona wersja oceny ryzyka sercowo-naczyniowego Pol-SCORE 2015 (źródło [2])

stwierdzono wówczas 90-procentowe zwężenie gałęzi międzykomorowej przedniej lewej tętnicy wieńcowej w segmencie 8., z wąskim obwodem na koniuszku (średnica $<2 \mathrm{~mm}$ ). Tętnica okalająca w odcinku proksymalnym była zwężona w 95\%. W prawej tętnicy wieńcowej stwierdzono zmiany brzeżne. Wówczas stężenie cholesterolu frakcji lipoprotein o niskiej gęstości (LDL-C, low-density lipoprotein cholesterol) u pacjenta wynosiło $110 \mathrm{mg} / \mathrm{dl}$, natomiast odsetek hemoglobiny glikowanej $7,1 \%$, a wskaźnik masy ciała (BMI, body mass index) $29 \mathrm{~kg} / \mathrm{m}^{2}$. Frakcja wyrzutowa lewej komory (LVEF, left ventricular ejection fraction) była zachowana (60\%) z niewielkimi odcinkowymi zaburzeniami kurczliwości o typie hipokinezy ściany dolnej oraz bocznej mięśnia sercowego. Po zabiegu przezskórnej interwencji wieńcowej ( $\mathrm{PCl}$, percutaneous coronary intervention) tętnicy okalającej chorego zakwalifikowano do dalszego leczenia zachowawczego choroby wieńcowej. Pozostawał on pod stałą opieką poradni kardiologicznej i przyjmował przewlekle:

- kwas acetylosalicylowy w dawce 75 mg raz/dobę;

- tikagrelol w dawce 90 mg 2 razy/dobę;
- atorwastatynę w dawce 40 mg raz/dobę;

- bisoprolol w dawce 2,5 mg raz/dobe;

- walsartan w dawce $80 \mathrm{mg}$ raz/dobę;

- teofilina w dawce 300 mg 2 razy/dobę według zaleceń pulmonologa;

- gliklazyd w preparacie o przedłużonym uwalnianiu w dawce $60 \mathrm{mg}$ raz/dobę.

Po 1,5 roku podczas kolejnych wizyt ambulatoryjnych u pacjenta następowało stopniowe pogorszenie kontroli ciśnienia tętniczego, glikemii oraz zaburzeń lipidowych. Pacjent przyznał, że nie przyjmuje systematycznie statyny oraz okresowo pali papierosy. Stężenie glukozy wynosiło 200 mg/dl na czczo, występowały skoki ciśnienia tętniczego do 180/100 mm Hg. Istniało również podejrzenie, że pacjent nie przyjmował systematycznie leków hipotensyjnych. Odmówił wykonania ambulatoryjnej oceny całodobowego monitorowania ciśnienia tętniczego (ABPM, ambulatory blood pressure monitoring).

Z powodu zgłaszanych dolegliwości bólowych w klatce piersiowej o nietypowym charakterze w styczniu 2018 roku wykonano u pacjenta scyntygrafię perfuzyjną mięśnia 
sercowego. Pacjent osiągnął 10,1 MET. Próba była ujemna klinicznie, słabo dodatnia elektrokardiograficznie na ścianie bocznej. Wykryto utrwalone zmniejszenie wychwytu na ścianie dolnej do 10-15\%. Chorego zakwalifikowano do dalszego leczenia zachowawczego.

W związku z zaistniałą sytuacją zmodyfikowano leczenie, włączając peryndopryl w dawce $10 \mathrm{mg}$ w miejsce walsartanu w dawce $80 \mathrm{mg}$ oraz dołączono amlodipinę w dawce $10 \mathrm{mg}$. Warto przypomnieć, że w przypadku pacjentów z nadciśnieniem tętniczym i stabilną chorobą wieńcową (SCAD, stable coronary artery disease) inhibitory konwertazy angiotensyny (ACE, angiotensin-converting enzyme) są lekami pierwszego wyboru, a antagoniści receptora dla angiotensyny II (ARB, angiotensin receptor blocker) stanowią alternatywę dla inhibitorów ACE tylko w przypadku istnienia przeciwwskazania lub nietolerancji inhibitorów ACE. Po osiągnięciu docelowych wartości ciśnienia tętniczego (128/75 mm Hg; cel wg wytycznych ESC/ESH dotyczących nadciśnienia z 2018 r. u pacjentów z nadciśnieniem tętniczym i SCAD wynosi 120-129/70-79 mm Hg), ze względu na wcześniejsze nieprzestrzeganie zaleceń przez pacjenta, podjęto decyzję o zmianie leczenia z wykorzystaniem preparatów złożonych. Zalecono następujące leki:

- złożony lek hipotensyjno-hipolipemizujący zawierający $40 \mathrm{mg}$ atorwastatyny, $10 \mathrm{mg}$ peryndoprylu oraz $10 \mathrm{mg}$ amlodipiny raz/dobę rano;

- bisoprolol w dawce 7,5 mg raz/dobę;

- kwas acetylosalicylowy w dawce $75 \mathrm{mg}$ raz/dobę;

- teofilina w dawce 300 mg 2 razy/dobe,, według zaleceń pulmonologa;

- rozpoczęto insulinoterapię, zważywszy na niewłaściwą kontrolę glikemii.

Chorego poinformowano ponadto o bezwzględnym zakazie palenia tytoniu. Zalecono mu ograniczenie spożycia soli do $5 \mathrm{~g} /$ dobę, dietę ubogocholesterolową i cukrzycową oraz regularny wysiłek fizyczny 30 min dziennie.

Ocenę kontrolną przeprowadzono u pacjenta 2 miesiące po zmodyfikowaniu farmakoterapii. Chory nie zgłaszał dolegliwości ani skoków ciśnienia tętniczego. Cel terapeutyczny został osiągnięty w zakresie ciśnienia tętniczego, które w warunkach domowych wynosiło 125-130/75-80 mm Hg oraz w zakresie hipercholesterolemii (tab. 4) dla osób z udokumentowaną chorobą wieńcową (chory z grupy bardzo wysokiego ryzyka), tj. cel terapeutyczny dla LDL-C poniżej $70 \mathrm{mg} / \mathrm{dl}$.

\section{Dyskusja}

W Polsce u 2 chorych na 3 z nadciśnieniem tętniczym występuje hipercholesterolemia [3]. Podwaja ona ryzyko CV u pacjentów z nadciśnieniem tętniczym [4]. Według badania NATPOL 2011 [5] hipercholesterolemia w Polsce jest skutecznie leczona jedynie u $11 \%$ chorych, a nadciśnienie tętnicze u $26 \%$. Miejsce statyn w ostatnich wytycznych leczenia nadciśnienia tętniczego ESC/ESH 2018 jest wysoko pozycjonowane. W myśl tych wytycznych izolowana terapia hipotensyjna u pacjentów z nadciśnieniem tętniczym obciążonych umiarkowanym lub wyższym ryzykiem CV albo z rozpoznaną CVD zwykle nie jest w stanie obniżyć ryzyka CV. Należy w tej grupie dołączyć statynę. Warto podkreślić, że powyższe korzyści z dołączenia statyny odnoszą również pacjenci, u których ciśnienie tętnicze jest dobrze kontrolowane [1]. Według aktualnych zaleceń stosowanie statyny należy również rozważyć u pacjentów z nadciśnieniem tętniczym cechujących się niskim lub umiarkowanym ryzykiem CV, aby osiągnąć stężenie LDL-C poniżej $115 \mathrm{mg} / \mathrm{dl}$ [1].

Przedstawiony przypadek ukazuje, że intensywna optymalizacja terapii pozwala osiągnąć w krótkim czasie cele terapeutyczne u pacjenta z grupy bardzo wysokiego ryzyka CV z chorobą wieńcową, obciążonego licznymi czynnikami ryzyka i tym samym poprawić jego rokowanie CV.

W badaniu ASCOT-LLA (Anglo-Scandinavian Cardiac Outcomes Trial - Lipid Lowering Arm) udokumentowano, że $10 \mathrm{mg} /$ dobę atorwastatny stosowanej u pacjentów z nadciśnieniem tętniczym i obciążonych co najmniej trzema innymi czynnikami ryzyka CV obniża ryzyko zawału serca o około $1 / 3$ oraz ryzyko udaru o około 1/4. Korzyści z leczenia odnotowywano już w 1. roku po dołączeniu atorwastatyny (ryc. 1) [6]. Dołączenie atorwastatyny w dawce $10 \mathrm{mg} /$ dobę

Tabela 4. Ciśnienie tętnicze i lipidogram pacjenta przed zmianą leczenia oraz po niej

\begin{tabular}{lcc} 
Parametr & \multicolumn{2}{c}{ Ciśnienie tętnicze i lipidogram pacjenta } \\
& Przed modyfikacją terapii & Po modyfikacji terapii \\
Skurczowe ciśnienie tętnicze $[\mathrm{mm} \mathrm{Hg}]$ & 180 & $125-130$ \\
Rozkurczowe ciśnienie tętnicze $[\mathrm{mm} \mathrm{Hg}]$ & 100 & $75-80$ \\
Stężenie LDL-C [mg/dl] & 81 & 65 \\
Stężenie HDL-C [mg/dl] & 45 & 39 \\
Stężenie triglicerydów [mg/dl] & 116 & 102 \\
Stężenie cholesterolu całkowitego [mg/dl] & 159 & 139 \\
LDL-C (low-density lipoprotein cholesterol) - cholesterol frakcji lipoprotein o niskiej gęstości; HDL-C (high-density lipoprotein cholesterol) - cholesterol frakcji lipoprotein o wysokiej gęstości
\end{tabular}




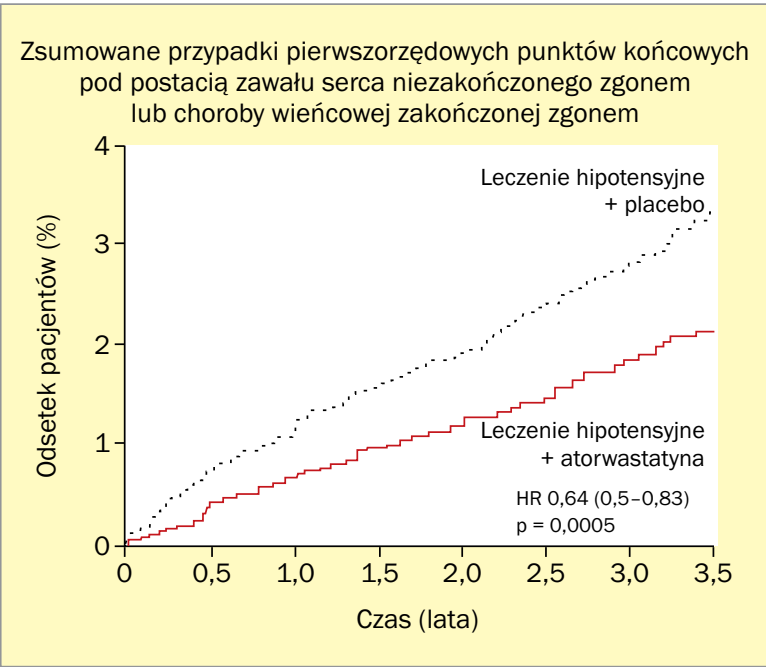

Rycina 1. Punkty końcowe w badaniu ASCOTT-LLA (zmodyfikowano wg [6]); HR (hazard ratio) - współczynnik ryzyka

do leczenia hipotensyjnego wiązało się z 36-procentowym ograniczeniem częstości zakończonych i niezakończonych zgonem zawałów, 29-procentowym zmniejszeniem częstości incydentów wieńcowych oraz 27-procentowym zmniejszeniem częstości udarów zakończonych i niezakończonych zgonem [6]. Uzyskano 3 razy lepszą ochronę przed zawałem serca w przypadku stosowania połączenia atorwastatyny z peryndoprylem/amlodipiną w porównaniu z połączeniem atorwastatyny $z$ atenololem/tiazydem (ryc. 2). Ponadto na podstawie 16-letnich obserwacji pacjentów z badania ASCOTT-LLA Gupta i wsp. [7] przedstawili, że dołączenie do leków hipotensyjnych statyny w porównaniu z placebo obniża śmiertelność CV o 15\% \{współczynnik ryzyka [HR, hazard ratio] 0,85 (95-proc. przedział ufności [Cl, confidence interval] 0,72-0,99); $p=0,0395$.

Według skali Pol-SCORE każdy chorujący na nadciśnienie tętnicze mężczyzna powyżej 55. roku życia oraz każda kobieta powyżej 65. roku życia w populacji polskiej są obciążeni wysokim lub bardzo wysokim ryzykiem zgonu z przyczyn CV w ciągu 10 lat, dlatego powinni przyjmować statynę nawet przy prawidłowym lipidogramie.

Z kolei wyniki badania POL-FOKUS wskazują, że 7 na 10 pacjentom z nadciśnieniem tętniczym równolegle z lekami hipotensyjnymi jest przepisywana statyna, natomiast prawidłową kontrolę LDL-C osiąga zaledwie 4 spośród tych 7 pacjentów [8]. Prawdopodobnymi przyczynami takiego stanu rzeczy są niski poziom adherence i zbyt małe dawki statyn.

Kolejnym ważnym aspektem, który należy wziąć pod uwagę $\mathrm{w}$ terapii pacjentów z nadciśnieniem tętniczym, jest palenie tytoniu. Według skali Pol-SCORE 2015 wszyscy palący mężczyźni powyżej 55. roku życia należą do grupy wysokiego lub bardzo wysokiego ryzyka CV niezależnie od kontroli ciśnienia tętniczego oraz zaburzeń lipidowych. Ponadto w badaniu GREACE (GREek Atorvastatin and Coronary-heart-disease Evaluation), do którego włączono 1600 pacjentów ze stabilną chorobą wieńcową, stwierdzono, że dołączenie atorwastatyny u osób wciąż palących papierosy znacznie obniżyło ryzyko zgonu w porównaniu z pacjentami palącymi i nieprzyjmującymi atorwastatyny [9]. Na podstawie tego samego badania należy podkreślić, że pacjenta palącego, który przyjmuje atorwastaynę, wciąż cechuje znacząco wyższe ryzyko zgonu niż pacjenta nigdy niepalącego lub byłego palacza [9]. Według badania przeprowadzonego w Stanach Zjednoczonych przez Chapman i wsp. [10] adherence pacjentów leczonych z powodu nadciśnienia tętniczego i hiperlipidemii znacznie się pogarsza

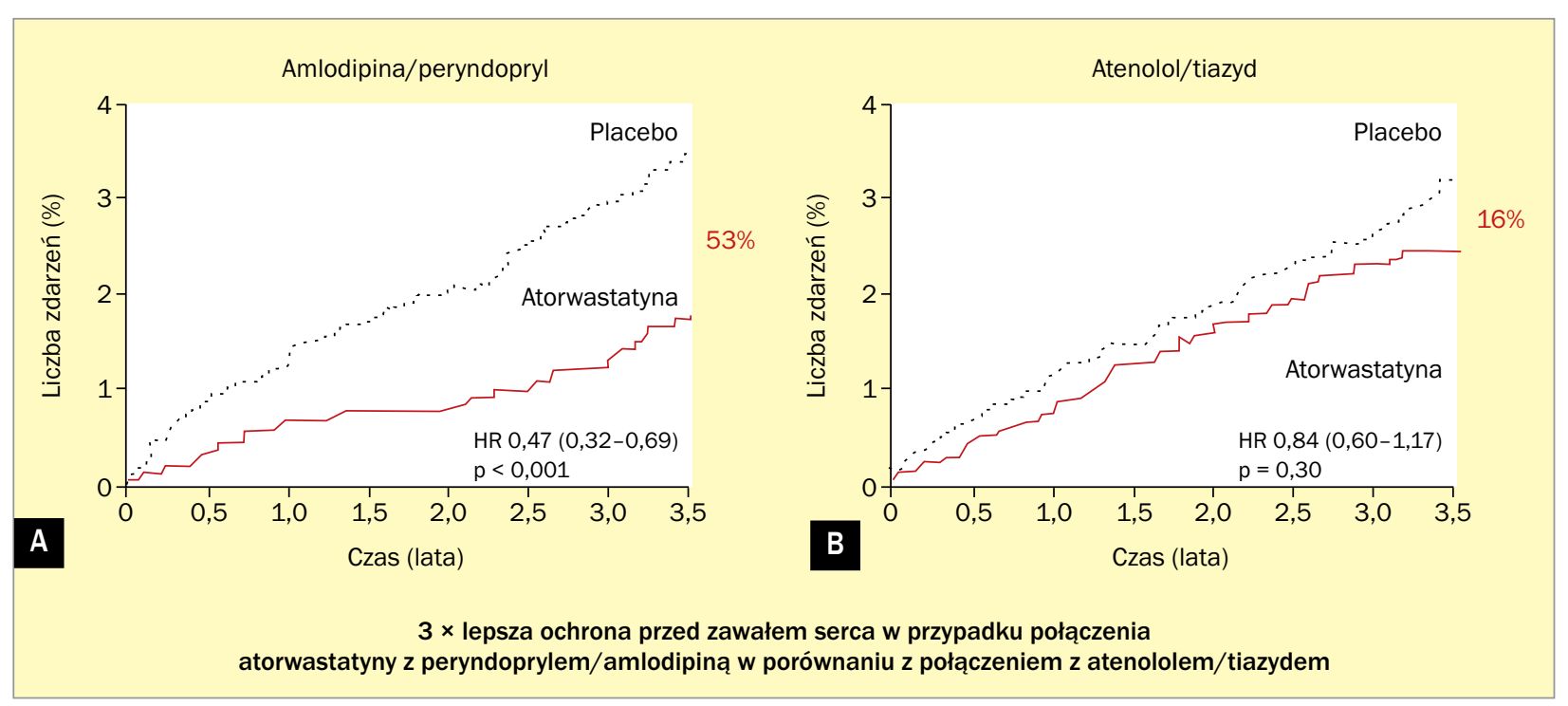

Rycina 2A, B. Synergia atorwastatyny, peryndoprylu i amlodipiny w protekcji sercowo-naczyniowej (badanie ASCOT-LLA) (zmodyfikowano wg [6]); HR (hazard ratio) - współczynnik ryzyka 


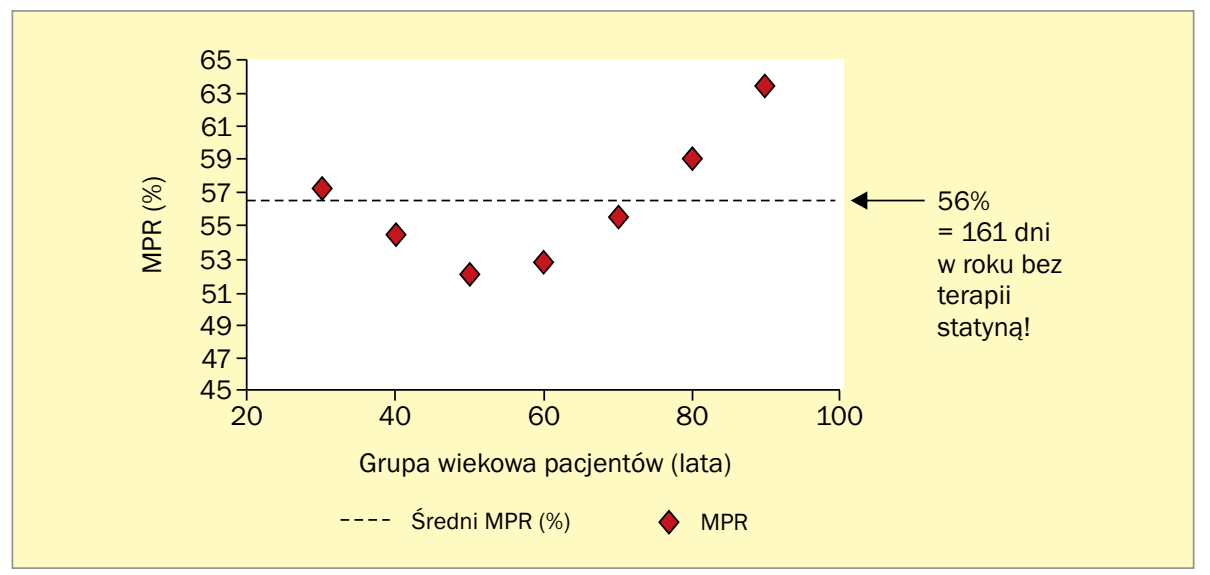

Rycina 3. Adherence w przypadku statyn w Polsce (na podstawie [13, 14]); MPR (medical possesion ratio) - wskaźnik posiadania (zażywania) leku (statyny)

po pierwszych 6 miesięcach od rozpoczęcia terapii i wynosi zaledwie 35,8\%. Autorzy tego badania wskazują, że zmniejszenie liczby przyjmowanych przez pacjenta tabletek przy rozpoczynaniu terapii nadciśnienia tętniczego i hiperlipidemii może poprawiać adherence pacjentów [10].

W 2017 roku Awad i wsp. [11] przedstawili na łamach „Journal of Clinical Lipidology” wyniki metaanalizy, w której udokumentowali, że statyn długodziałających, takich jak atorwastatyna lub rosuwastatyna, pacjenci nie muszą stosować wyłącznie wieczorem. Mogą być one również przyjmowane w godzinach porannych, jeżeli umożliwi to lepszy compliance ze strony pacjenta [11].

Wiadomo, że przyjmowania statyn przestrzega zaledwie $57 \%$ pacjentów w prewencji pierwotnej i $76 \%$ w prewencji wtórnej [12]. Dane polskie z Narodowego Funduszu Zdrowia (NFZ) wskazują na niski wskaźnik stosowania statyny wśród polskich pacjentów niemal w każdej grupie wiekowej. Wskaźnik ten jest najniższy wśród pacjentów między 40. a 70. rokiem życia. Są to osoby aktywne zawodowo, niemające czasu zadbać o swoje zdrowie, a przy tym z długą perspektywą przeżyciową. Średni wskaźnik zażywania statyn w grupie polskich pacjentów to $56 \%$, co oznacza 161 dni bez terapii statyną w roku (ryc. 3) [13, 14]. Wydaje się, że szansą na zmianę tej statystki są leki złożone hipotensyjno-hipolipemizujące. Terapia lekami złożonymi w porównaniu z terapią lekami stosowanymi osobno zwiększa adherence [15].

Należy podkreślić, że podstawy w zakresie medycyny opartej na faktach (EBM, evidence-based medicine) w odniesieniu do nowoczesnej terapii hipotensyjno-hipolipemizującej 3-składnikowym lekiem złożonym atorwastatyna/ /peryndopryl/amlodipina są mocne. Dane literaturowe wskazują na synergistyczne działanie tych 3 leków pod względem zwiększenia stabilności blaszki miażdżycowej i poprawy różnicowania komórek mięśni gładkich, co prowadzi do korzystnego wpływu na układ CV. Właściwości przeciwmiażdżycowe udowodniono w przypadku wszystkich składowych leku. Hamują dysfunkcję śródbłonka, oksydację LDL-C, proliferację, migrację komórek mięśni gładkich i rozpad włóknistej pokrywy blaszki miażdżycowej. Wszystkie te działania przyczyniają się do zmniejszenia tworzenia nowych blaszek miażdżycowych i zwiększenia stabilności blaszek już istniejących.

Wykazano, że amlodipina hamuje powstawanie skupisk zmodyfikowanych cząsteczek LDL-C, co zapobiega powstawaniu komórek piankowatych. Ponadto, mimo że wszystkie leki przeciwnadciśnieniowe obniżają ciśnienie tętnicze, to nie wszystkie wpływają na sztywność aorty i centralne parametry hemodynamiczne. W licznych badaniach potwierdzono przewagę antagonistów układu renina-angiotensyna-aldosteron (RAA) i antagonistów wapnia nad diuretykami i beta-adrenolitykami pod względem wpływu na sztywność tętnic oraz centralne ciśnienie tętnicze i odbicie fali tętna. Wazodylatacyjne działanie inhibitorów konwertazy angiotensyny (ACE, angiotensin-converting enzyme) i antagonistów wapnia prowadzi do zmniejszenia prędkości fali tętna w aorcie, opóźniając powrót odbitej fali tętna z obwodu do serca i jednocześnie zmniejszając jej amplitudę dzięki rozszerzeniu mięśni tętnic. Zmiany parametrów fali odbitej obniżają centralne ciśnienie skurczowe i ciśnienie tętna, co przekłada się na korzyści kliniczne. Statyny również zmniejszają sztywność tętnic u chorych z hipercholesterolemią i u chorych obciążonych wysokim ryzykiem CV, w perspektywie zarówno krótko-, jak i długoterminowej [16-19].

\section{Podsumowanie}

Równoczesna kontrola nadciśnienia tętniczego i hipercholesterolemii nie jest łatwa do uzyskania w codziennej praktyce. W wytycznych dominuje stanowisko większej skuteczności klinicznej preparatów złożonych, co łączy się 
z ograniczeniem liczby przyjmowanych przez pacjenta tabletek oraz lepszym przestrzeganiem przez niego zaleceń. W nowych wytycznych ESC/ESH dotyczących diagnostyki i leczenia nadciśnienia tętniczego 2018 podkreśla się, że izolowana terapia hipotensyjna chorych na nadciśnienie tętnicze obciążonych umiarkowanym lub wysokim ryzykiem CV, lub z rozpoznaną CVD zwykle nie jest w stanie optymalnie obniżyć ryzyka u tych pacjentów. Wskazuje się na korzyści kliniczne z przyjmowania statyny, nawet jeżeli ciśnienie tętnicze jest dobrze kontrolowane.

U opisanego pacjenta z grupy bardzo wysokiego ryzyka CV dzięki zastosowaniu 3-składnikowego preparatu złożonego atorwastatyna/peryndopryl/amlodipina w krótkim czasie uzyskano optymalny efekt terapeutyczny. Autorzy mają nadzieję, że nowoczesna terapia 3-składnikowym preparatem złożonym, w skład którego wchodzą statyna i 2 leki hipotensyjne, pozwoli uniknąć u tego pacjenta powikłań CV. Warto zwrócić również uwagę, że lekarz - stosując statynę w połączeniu z lekami hipotensyjnymi w jednej tabletce przy osiągnięciu efektu hipotensyjnego ma pewność, że pacjent przyjmuje lek hipolipemizujący. W badaniach nad tabletkami wieloskładnikowymi wykazano, że ich stosowanie wiązało się ze średnio 44-procentowym wzrostem przestrzegania zaleceń lekarskich w zakresie farmakoterapii [20]. Reasumując, stosowanie leków złożonych umożliwia lepszą kontrolę adherence również ze strony lekarza.

\section{Abstract}

New ESC/ESH 2018 guidelines for the management of arterial hypertension (AH), once again emphasise the significance of evaluating the total cardiovascular risk in patients with hypertension. Total cardiovascular risk evaluation will determine the appropriate medication and the best therapeutic strategy. Combination drug therapy improves adherence, is much more convenient for patients, and is recommended under the new guidelines. Most hypertension patients have hypercholesterolemia. We describe the case of a very high cardiovascular risk patient with $\mathrm{AH}$, in which combination drug therapy (antihypertensive and cholesterol-lowering) proved to be swiftly effective.

Słowa kluczowe: guidelines, arterial hypertension, combination drug

Folia Cardiologica 2019; 14, 1: 112-119

\section{Piśmiennictwo}

1. Williams B, Mancia G, Spiering W, et al. ESC Scientific Document Group. 2018 ESC/ESH Guidelines for the management of arterial hypertension. Eur Heart J. 2018; 39(33): 3021-3104, doi: 10.1093/ /eurheartj/ehy339, indexed in Pubmed: 30165516.

2. Zdrojewski T, Jankowski P, Bandosz P, et al. [A new version of cardiovascular risk assessment system and risk charts calibrated for Polish population]. Kardiol Pol. 2015; 73(10): 958-961, doi: 10.5603/ /KP.2015.0182, indexed in Pubmed: 26521843.

3. Czarnecka D, Stolarz-Skrzypek K, Bednarski A, et al. Therapeutic strategies in poorly controlled hypertension in outpatient setting in Poland - POSTER study. Folia Cardiol. 2015; 10(4): 242-248.

4. Jackson R, Lawes CMM, Bennett DA, et al. Treatment with drugs to lower blood pressure and blood cholesterol based on an individual's absolute cardiovascular risk. Lancet. 2005; 365(9457): 434-441, doi: 10.1016/S0140-6736(05)17833-7, indexed in Pubmed: 15680460.

5. Zdrojewski T, Solnica B, Cybulska B, et al. Prevalence of lipid abnormalities in Poland. The NATPOL 2011 survey. Kardiol Pol. 2016; 74(3): 213-223, doi: 10.5603/KP.2016.0029, indexed in Pubmed: 27004543.

6. Sever PS, Dahlöf B, Poulter NR, et al. ASCOT Investigators. Prevention of coronary and stroke events with atorvastatin in hypertensive patients who have average or lower-than-average cholesterol concentrations, in the Anglo-Scandinavian Cardiac Outcomes Trial - Lipid Lowering Arm (ASCOT-LLA): a multicentre randomised controlled trial. Lancet. 2003; 361(9364): 1149-1158, doi: 10.1016/S01406736(03)12948-0, indexed in Pubmed: 12686036.
7. Gupta A, Mackay J, Whitehouse A, et al. Long-term mortality after blood pressure-lowering and lipid-lowering treatment in patients with hypertension in the Anglo-Scandinavian Cardiac Outcomes Trial (ASCOT) Legacy study: 16-year follow-up results of a randomised factorial trial. Lancet. 2018; 392(10153): 1127-1137, doi: 10.1016/ /S0140-6736(18)31776-8, indexed in Pubmed: 30158072.

8. Prejbisz A, Klocek M, Gąsowski J, et al. Factors associated with resistant hypertension in a large cohort of hypertensive patients: the Pol-Fokus study. Pol Arch Med Wewn. 2015; 125(4): 249-259, indexed in Pubmed: 25764004.

9. Athyros VG, Tziomalos K, Katsiki N, et al. GREACE Study Collaborative Group. The impact of smoking on cardiovascular outcomes and comorbidities in statin-treated patients with coronary artery disease: a post hoc analysis of the GREACE study. Curr Vasc Pharmacol. 2013; 11(5): 779-784, doi: 10.2174/1570161111311050016, indexed in Pubmed: 23140546.

10. Chapman RH, Benner JS, Girase P, et al. Predictors of adherence with antihypertensive and lipid-lowering therapy. Arch Intern Med. 2005; 165(10): 1147-1152, doi: 10.1001/archinte.165.10.1147, indexed in Pubmed: 15911728.

11. Awad K, Serban MC, Penson P, et al. Lipid and Blood Pressure Meta-analysis Collaboration (LBPMC) Group. Effects of morning vs evening statin administration on lipid profile: a systematic review and meta-analysis. J Clin Lipidol. 2017; 11(4): 972-985.e9, doi: 10.1016/j. jacl.2017.06.001, indexed in Pubmed: 28826569. 
12. Naderi SH, Bestwick JP, Wald DS. Adherence to drugs that prevent cardiovascular disease: meta-analysis on 376,162 patients. Am J Med. 2012; 125(9): 882-887.e1, doi: 10.1016/j.amjmed.2011.12.013, indexed in Pubmed: 22748400.

13. Wiśnowska B, Skowron A. Ocena przestrzegania zaleceń lekarskich w terapii hipercholesterolemii. Farm Przegl Nauk. 2009; 11: 42-47.

14. Wiśniowska B, Skowron A. Evaluation of patients' adherence to statins in Poland. Curr Med Res Opin. 2011; 27(1): 99-105, doi: 10.1185/03007995.2010.536745, indexed in Pubmed: 21091392.

15. Pan F, Chernew ME, Fendrick AM. Impact of fixed-dose combination drugs on adherence to prescription medications. J Gen Intern Med. 2008; 23(5): 611-614, doi: 10.1007/s11606-008-0544-x, indexed in Pubmed: 18288541.

16. Rubba P. Effects of atorvastatin on the different phases of atherogenesis. Drugs. 2007; 67(Suppl 1): 17-27, doi: 10.2165/00003495200767001-00003, indexed in Pubmed: 17910518.
17. Mason RP. Mechanisms of plaque stabilization for the dihydropyridine calcium channel blocker amlodipine: review of the evidence. Atherosclerosis. 2002; 165(2): 191-199, indexed in Pubmed: 12417269.

18. Ferrari R. Optimizing the treatment of hypertension and stable coronary artery disease: clinical evidence for fixed-combination perindopril/amlodipine. Curr Med Res Opin. 2008; 24(12): 3543-3557, doi: 10.1185/03007990802576302, indexed in Pubmed: 19032136.

19. Sever P, Dahlöf B, Poulter N, et al. ASCOT Steering Committee Members. Potential synergy between lipid-lowering and blood-pressure-lowering in the Anglo-Scandinavian Cardiac Outcomes Trial. Eur Heart J. 2006; 27(24): 2982-2988, doi: 10.1093/eurheartj/ehl403, indexed in Pubmed: 17145722.

20. Huffman MD. The polypill: from promise to pragmatism. PLoS Med. 2015; 12(8): e1001862, doi: 10.1371/journal.pmed.1001862, indexed in Pubmed: 26263422. 